\title{
The effect of NATURA 2000 network on the Eurasian Eagle-owl (Bubo bubo) population in Southeast Bulgaria: implications for conservation
}

\author{
Boyan MiLCheV ${ }^{1 *} \&$ Valeri GeORGIEV ${ }^{2}$
}

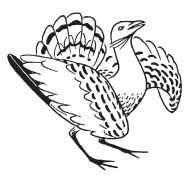

Received: May 06, 2021 - Revised: May 27, 2021 -Accepted: May: 28, 2021

Milchev, B. \& Georgiev, V. 2021. The effect of Natura 2000 network on the Eurasian Eagleowl (Bubo bubo) population in Southeast Bulgaria: implications for conservation. - Ornis Hungarica 29(1): 170-178. DOI: 10.2478/orhu-2021-0013

\begin{abstract}
The effectiveness and efficiency of the NATURA 2000 network for the Eurasian Eagle-owl conservation in SE Bulgaria was assessed by comparing data collected during a long-term study on number of breeding pairs and fledglings before and after network establishment. The NATURA 2000 network and non-protected areas showed similar values of the calculated indices according to the number of occupied localities. However, the pairs in NATURA 2000 sites bred significantly less fledglings after the creation of the network than the pairs in nonprotected ones. The Special Protection Areas (SPA) system created specifically for the preservation of birds has the lowest efficiency in respect to Eurasian Eagle-owl protection. Proposals were made after 'gap analysis' for real protection and optimization of the protected-area network to increase the stability of the Eurasian Eagle-owl population in the changing environment.
\end{abstract}

Keywords: conservation goals, conservation effectiveness, top predator, Special Protection Areas, Special Areas of Conservation

Összefoglalás Délkelet-Bulgária területén hosszú távú vizsgálat alapján elemeztük a NATURA 2000 hálózat hatékonyságát és eredményességét az uhu konzervációbiológiájában, amelyhez számos, a hálózat kijelölése előtti és utáni időszakban gyüjtött költőpár és fióka adatait használtuk fel. A NATURA 2000-es hálózat és a nem védett területek esetén az elfoglalt területek száma szerint számított mutatók hasonlóak voltak. A NATURA 2000-es területeken költő párok a hálózat kijelölése után azonban szignifikánsan kevesebb kirepült fiókát neveltek fel, mint a nem védett területeken fészkelő párok. A kifejezetten a madarak megőrzésére létrehozott SPA rendszer az uhu védelmét tekintve a legkevésbé hatékony. A gap-elemzést követően javaslatot tettünk a védelem hatékonyságának javítására és a védett területek hálózatának optimalizálására annak érdekében, hogy növeljük az uhu populáció stabilitását a változó környezetben.

Kulcsszavak: konzervációs célok, konzerváció hatékonyság, csúcsragadozó, különleges madárvédelmi terület, különleges természetmegörzési terület

\footnotetext{
${ }^{1}$ University of Forestry, Wildlife Management Department, 10 Kl. Ochridski Blvd., BG-1756 Sofia, Bulgaria

${ }^{2}$ Ministry of Environment and Water, 22 Maria Luisa Blvd., BG-1000 Sofia, Bulgaria

*corresponding author, e-mail: boyan.m@abv.bg
} 


\section{Introduction}

The preservation and sustainable use of wildlife in protected areas are among the largely used global practices (Margules \& Pressey 2000, Watson et al. 2014, Geldmann et al. 2019). The EU's Natura 2000 network is the largest system in the world covering onefifth of the union land area (European Commission 2021). Its main target is to preserve biodiversity of the continent in the process of accelerated economic development (Trochet \& Schmeller 2013, Gantioler et al. 2014). Bulgaria designated its Natura 2000 network in time of the accession to EU in 2007 and nowadays it covers $34.9 \%$ of the territory of the country. Both groups of sites in the network namely Special Protection Areas (SPA) with $23.1 \%$ and Special Areas of Conservation (SAC) with 30.3\% designated, respectively, under the EU Birds Directive and the EU Habitats Directive, largely overlap (website of the Ministry of Environment and Water 2021). The existing National Protected Areas network (NPA) as parks and reserves, and smaller protected areas designated according to the national Protected Areas Act served as base for development of NATURA 2000 in Bulgaria and most of them were included in SPAs and SACs. The change of the Nature protection legislation in 2002 followed by the creation of national NATURA 2000 network in 2007 intend to maintain and restore the conservation status of priority habitats and species.

Top predators are keystones in the conservation strategy as an integral part of biodiversity and their great importance for ecological community dynamics (Sergio et al. 2006, 2008, Regos et al. 2017). They are usual flagships to promote nature protection, and important for the economic benefits of local communities from nature-friendly management of protected areas (Burgas et al. 2014, di Minin \& Moilanen 2014). The Eurasian Eagleowl (Bubo bubo) is the largest and strongest nocturnal avian predator, the least concern and increasing European population of which has an unfavorable conservation status in the continent (BirdLife International 2017). The Bulgarian population is stable estimated to 450-550 pairs but depleted from a decline suffered during the last century (BirdLife International 2017). The National Red Data Book included the Eurasian Eagle-owl as an endangered species (Golemanski 2015). The Eurasian Eagle-owl is listed in Annex I of the EU Birds Directive and requires designation of SPAs in NATURA 2000 network. Therefore, the status of its population before and after the creation of the national NATURA 2000 network is indicative of the effectiveness of the protection-area systems.

The present study assesses the role of the protected-area system with respect to the Eurasian Eagle-owl population in SE Bulgaria through: i) determining the effectiveness and efficiency of the three systems of protected areas according to the breeding distribution; ii) specifying the fledgling effectiveness and fledgling efficiency of the protected-area systems based on the fledgling production. We expect SPAs to be the most effective protected-area system as they have been declared specifically for preservation of birds. We expect the breeding pairs in protected-area systems to produce significantly more fledglings after establishment of the NATURA 2000 network in comparison to those in non-protected areas. 


\section{Material and Methods}

The study covered an area of about $10,000 \mathrm{~km}^{2}$ in southeastern Bulgaria, $9 \%$ of the country $\left(42^{\circ} 22^{\prime} 00^{\prime}\right.$ N $\left.27^{\circ} 00^{\prime} 00^{\prime \prime} \mathrm{E}\right)$ (Figure 1). The predominant relief is hilly and flat with arable lands, pastures, oasis and riparian deciduous forests with mainly a continental Mediterranean climate (see also Milchev et al. 2019). Several low mountains and hills with a height usually up to 300-400 m a.s.l. are located in the southern part near the border with Turkey. Deciduous forests with predominance of oaks (Quercus sp.) cover this border area. The forest area decreases from east to west, being replaced by arable land and pastures on flattened ridges and gradual slopes. The depopulation of villages and small towns has been an ongoing process in the region, especially since 1990 due to political changes. The Black Sea coast is much less affected by depopulation because of coastal resort development and tourism growth. The three protected-area systems cover $47.9 \%$ of the study area (marine waters are excluded as they are not a habitat of the Eurasian Eagle-owl) (Figure 1). The protected-area network includes mainly the southern state border area and the Black Sea coast.

The Eurasian Eagle-owl is a rock-nesting species in the area and its distribution depends on the available rock complexes with possibility of undisturbed breeding (Milchev et al. 2019). The diet is very diverse and with significant temporal changes in the dominant structure both in individual territories (Milchev 2016, Milchev \& Spassov 2017) and at the population level (Milchev \& Georgiev 2020). Data for breeding distribution and output were collected during the period 2000-2013 and included a 7-year interval before and after the establishment of NATURA 2000 network (Milchev et al. 2019). This long-term study avoids possibility of misjudgment due to incomplete or short-term occurence of data. Comparisons between the protected and non-protected areas were based on:

(1) number of occupied breeding localities: the least evidences of an occupied rocky complex by Eurasian Eagle-owls were their excrements and food remains;

(2) number of fledglings that reached the age of 45-50 days. Older fledglings are hard to find because they tend to stray from the nest (Penteriani \& Delgado 2019);

(3) fledglings rate: number of fledglings per successful pair.

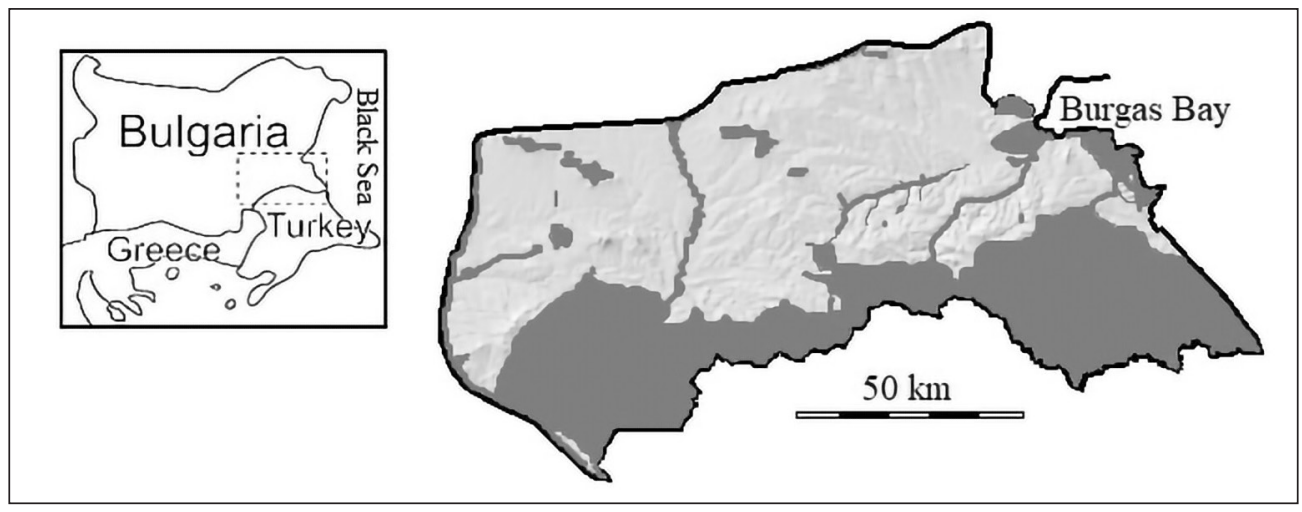

Figure 1. Study area in SE Bulgaria with marked protected-area network

1. ábra A mintavételi terület Délkelet-Bulgáriában, jelölve a védett területek hálózatát 
The indices of effectiveness, efficiency (Abellán et al. 2011), fledgling effectiveness and fledgling efficiency of the three protected-area systems and their combined importance for the breeding popuation of the Earasian Eagle-owl in SE Bulgaria were computed:

(a) Effectiveness index, defined as the proportion of breeding localities included within the system s: Effectiveness $=\mathrm{Ns} / \mathrm{N}$, where Ns is the number of localities protected by system $\mathrm{s}$, and $\mathrm{N}$ is the total number of localities.

(b) Efficiency index, defined as the proportion of breeding localities included within the system $s$ in relation to the surface of the system: Efficiency $=\mathrm{Ns} /\left(\mathrm{N}^{*} \mathrm{As}\right)$, where As is the proportion of land surface of the study area protected by the system $\mathrm{s}$.

(c) Fledgling effectiveness index, defined as the proportion of fledglings of Eurasian Eagle-owl bred within the system s: Fledgling effectiveness $=F s / F$, where Fs is the number of fledglings bred within the system $\mathrm{s}$, and $\mathrm{F}$ is the total number of fledglings.

(d) Fledgling efficiency index, defined as the proportion of fledglings bred within the system $\mathrm{s}$ in relation to the surface of the system: Fledgling efficiency $=\mathrm{Fs} /\left(\mathrm{F}^{*} \mathrm{As}\right)$.

Differences between the numbers of occupied breeding territories and fledglings in protected and non-protected areas before and after establishment of NATURA 2000 network were calculated with a chi-square test applying Yates' correction. The significance level was $P<0.05$.

\section{Results}

The number of occupied breeding territories of Eurasian Eagle-owls increased slightly in both protected and non-protected areas after formation of NATURA 2000 network in 2007 and the change was insignificant $\left(\chi^{2}=0.0003, d f=1, P>0.05\right.$ ) (Table 1). The effectiveness index of the total protected-area network did not exceed the index for the non-protected area (Table 1). SACs were the most effective system with $95 \%$ of protected localities included $(\mathrm{n}=21$ localities). There was a cumulative effect of the three protected-area systems, which

Table 1. Effectiveness and efficiency of the protected area network in SE Bulgaria for the protection of the local Eurasian Eagle-owl (Bubo bubo) population

1. táblázat Délkelet-Bulgária ökológiai hálózatainak eredményessége és hatékonysága a lokális uhu (Bubo bubo) populáció védelmében

\begin{tabular}{|c|c|c|c|c|c|c|}
\hline \multirow{2}{*}{ Area } & \multicolumn{2}{|c|}{ Occupied localities } & \multirow{2}{*}{$\begin{array}{l}\text { Area } \\
\mathbf{k m}^{2}\end{array}$} & \multirow{2}{*}{ As } & \multirow{2}{*}{ Effectiveness } & \multirow{2}{*}{ Efficiency } \\
\hline & before 2007 & since 2007 & & & & \\
\hline NPA & $11(30.6 \%)$ & $9(21.4 \%)$ & 1238.9 & 0.12 & 0.21 & 1.79 \\
\hline SPA & $13(36.1 \%)$ & $12(28.6 \%)$ & 3683.0 & 0.37 & 0.29 & 0.77 \\
\hline SAC & $19(52.8 \%)$ & $20(47.6 \%)$ & 4142.5 & 0.41 & 0.48 & 1.15 \\
\hline $\begin{array}{l}\text { Protected } \\
\text { combined }\end{array}$ & $19(52.8 \%)$ & $21(50.0 \%)$ & 4789.2 & 0.48 & 0.50 & 1.04 \\
\hline Non-protected & $17(47.2 \%)$ & $21(50.0 \%)$ & 5210.8 & 0.52 & 0.50 & 0.96 \\
\hline TOTAL & 36 & 42 & 10000 & & & \\
\hline
\end{tabular}


Table 2. Breeding performances, fledgling effectiveness and efficiency indices of the Eurasian Eagle-owl (Bubo bubo) population in SE Bulgaria before and after establishment ot NATURA 2000 network in 2007

2. táblázat Az uhu (Bubo bubo) populáció szaporodási teljesítménye, a kirepülés eredményességi és hatékonysági indexe Délkelet-Bulgáriában a NATURA 2000 hálózat 2007-es kialakítása előtt és után

\begin{tabular}{|c|c|c|c|c|c|c|}
\hline \multirow[b]{2}{*}{ Area } & \multicolumn{2}{|c|}{ Fledglings } & \multicolumn{2}{|c|}{ Fledgling rate } & \multirow[b]{2}{*}{$\begin{array}{c}\text { Fledgling } \\
\text { effectiveness }\end{array}$} & \multirow[b]{2}{*}{$\begin{array}{l}\text { Fledgling } \\
\text { efficiency }\end{array}$} \\
\hline & before 2007 & since 2007 & $\begin{array}{l}\text { before } \\
2007\end{array}$ & $\begin{array}{l}\text { since } \\
2007\end{array}$ & & \\
\hline NPA & 41 (25.9\%) & $26(15.0 \%)$ & 2.2 & 1.7 & 0.15 & 1.25 \\
\hline SPA & $48(30.4 \%)$ & $46(26.6 \%)$ & 2.1 & 1.8 & 0.27 & 0.72 \\
\hline SAC & 76 (48.1\%) & 56 (32.4\%) & 2.1 & 1.9 & 0.32 & 0.79 \\
\hline $\begin{array}{l}\text { Protected } \\
\text { combined }\end{array}$ & 76 (48.1\%) & 62 (35.8\%) & 2.1 & 1.9 & 0.36 & 0.75 \\
\hline Non-protected & 82 (51.9\%) & $111(64.2 \%)$ & 2.0 & 1.8 & 0.64 & 1.23 \\
\hline Total & 158 & 173 & 2.1 & 1.8 & & \\
\hline
\end{tabular}

alone are less effective. However, it did not apply to the network efficiency. NPAs were the most efficient system in comparison to SPAs, which proved to be the least efficient system for the target species.

There was a significant association between raised fledglings and particular protected status of the breeding localities $\left(\chi^{2}=4.62, d f=1, P<0.05\right)$. Young Eurasian Eagle-owls fledged less frequently in the NATURA 2000 network after its establishment (Table 2). Pairs in the nonprotected area raised $64.2 \%$ of all fledglings $(n=173)$ for the same period. The fledgling rate of the population decreased from 2.1 to 1.8 fledglings after the establishment of the NATURA 2000 network. The decrease affected the breeding pairs equally in both protected and nonprotected areas.

The indices for fledgling effectiveness and fledgling efficiency of the protected-area network were about twice lower compared to their values for the non-protected area (Table 2). The fledgling efficiency index in NPAs stood out with a very high value among the three protected-area systems and was the only one to reach the value of the index in nonprotected areas. No cumulative effect was found in the value of the efficiency index from the superimposition of the three systems of protected areas.

\section{Discussion}

Protected-area networks are part of the natural environment and are subject to constant change mainly due to human activities, both positive and negative. The EU's NaturA 2000 network is crucial for reducing losses in environmental and landscape diversity, with changes remaining greater in surrounding non-protected areas (Kubacka \& Smaga 2019). Changes in SPAs and SACs have already been reported in Bulgaria (Nikolov et al. 2014), but without any alteration in the Eurasian Eagle-owl population and without taking into 
account the effectiveness of the protected area in comparison to the surrounding nonprotected area. The effectiveness and efficiency of the protected-area network for Eurasian Eagle-owl population in SE Bulgaria proved to be similar to those of the non-protected area. SPAs must have been the most effective and efficient protected-area system for the species. However, the efficiency index placed NPAs as the most efficient among the three systems according to the land surface and number of localities of the target species. The reason for this is primarily that 5 localities $(56 \%, \mathrm{n}=9)$ have been included in the NPA system at the author's suggestions to protect areas with high biodiversity and breeding localities of threatened birds (Milchev \& Georgiev 2014).

Differences in individual productivity among the population of territorial predators have long been known (Newton 1979). The qualities of the breeding territory and nesting site such as food supply, protection from human activities, enemies and competitors, climatic factors, but probably also the individual abilities of the territory owners are driving differences in the productivity among Eurasian Eagle-owl populations (Penteriani \& Delgado 2019). Therefore, reproductive output allows to assess whether the protected areas have included the more productive part of the population. Thus, investments in the creation and management of the NATURA 2000 network meant to ensure the sustainable state of the Eurasian Eagle-owl population that inhabits them (León-Ortega et al. 2017). The more productive part of the population in the protected network could support the population outside the protected areas, which is expected to suffer from more diverse and intensive negative human influences. The results demonstrated just the opposite in SE Bulgaria. The breeding pairs in the NATURA 2000 network produced significantly less fledglings after the establishment of the network, while the fledgling rate decreased synchronously in protected and non-protected areas. One reason is that the three protected-area systems did not have actual ranger protection to reduce the primary breeding losses in the study area from destroyed or disturbed nests by people (Milchev et al. 2019).

Food supply in the hunting territory usually defines the reproductive output of the Eurasian Eagle-owl (Penteriani \& Delgado 2019, Scherzinger \& Mebs 2020). The significant increase of superpredation (hunting predatory mammals and birds) in the diet of the study population (Milchev \& Georgiev 2020) was an indicator of deteriorating food supply and food stress (Penteriani \& Delgado 2019). Reduced fledgling rate of the population corresponded to this pattern in the dietary structure. The NATURA 2000 network mainly covers the area along the border with Turkey, which is most affected by depopulation, the decline of livestock, and the abandonment of arable land (Milchev \& Georgiev 2020). The diet of the pairs there (see Clusters 1, 3, 6, 7, Figure 4 in Milchev \& Georgiev 2020) included the highest values of superpredation and otherwise rare atypical prey such as many smaller species of open and wood-shrubby habitats after the establishment of the NATURA 2000 network. The combined impact of the crucial negative factors leading to breeding losses and poor food supply explain the low efficiency of the NATURA 2000 network in the region and the resulting lack of sustainable perspective for the Eurasian Eagle-owl population in SE Bulgaria. A similar combination of factors explained the extinction of Egyptian Vultures (Neophron percnopterus) (Milchev \& Georgiev 2014) from the region and the local decline of Lesser Spotted Eagles (Clanga pomarina) (Demerdzhiev et al. 2019). 


\section{Implications for conservation}

Investments in the creation and management of the NATURA 2000 network must ensure the sustainable development of the Eurasian Eagle-owl population. The poor and incommensurate effectiveness and efficiency of the protected-area network indicate the need for urgent changes in several directions after 'gap analysis' (Scott \& Schipper 2006).

1) Management gaps:

The NPA system does not provide security for breeding pairs due to the lack of legal and financial capacity for effective protection with rangers. Adequate management and security of the NPA system will improve the productivity of all species sensitive to or benefiting from human presence. These measures will boost the efficiency of the NATURA 2000 network, which includes the vast majority of the NPA system.

Breeding pairs in rocky quarries produced similar number of fledglings like in natural rocky complexes (Milchev et al. 2019). Environmentally-friendly management in quarries at list in the NATURA 2000 network will minimise the breeding losses of the Eurasian Eagleowl and other threatened bird species nesting there (Milchev et al. 2019, Rohrer et al. 2020).

2) Ecological gaps:

The protected-area network must be developed and take into account the current data on the status of the target species and habitats. Ecological gaps in the NATURA 2000 network with inadequate protection of the rodents Roach's Mouse-tailed Dormouse (Myomimus roachi) and Romanian Hamster (Mesocricetus newtoni) (Milchev \& Georgiev 2012) proved to be very similar to those of the Eurasian Eagle-owl in SE Bulgaria. Only the first rodent species was subsequently removed from the lists of priority species in these SACs, which Milchev and Georgiev (2012) cited as an example of species included in protected areas without proven localities. The protection of both mammals remains unresolved in SE Bulgaria, despite the conclusion of Nedyalkov et al. (2018) for adequate habitat presence in the NATURA 2000. Apparently, none of the rodent species prefer the protected areas designated for them as it is now the case with Eurasian Eagle-owl. Therefore, given the large area of the NATURA 2000 network in Bulgaria, we support the recommendation of Gantioler et al. (2014) for optimizing the protectedarea network in the member states where its area is well above the EU average. Much better effectiveness and efficiency of the NATURA 2000 network for the Eurasian Eagle-owl and other species from the Bird and Habitat Directives will be achieved if the network includes the already preferred parts of SE Bulgaria by the species themselves according to the studies of Milchev and Georgiev (2012), Milchev and Menzel (2017), Chobanov and Milchev (2020).

\section{Acknowledgements}

We express our deep gratitude to A. Kovachev, U. Georgiewa, M. Chelebiev, P. Arsov, M. Slavchev and G. Gruychev for their assistance in the field. Investigations were carried out with the financial support of J. Menzel throughout the period and H. Frey in 2005. We would like to thank the anonymous reviewers for their valuable comments. The authors declare that this study is in accordance with national legislation. 


\section{References}

Abellán, M., Martínez, J., Palazón, J., Esteve, M. \& Calvo, J. 2011. Efficiency of a protected-area network in a Mediterranean Region: A multispecies assessment with Raptors. - Environmental Management 47: 983-991. DOI: $10.1007 / \mathrm{s} 00267-011-9640-5$

BirdLife International 2017. European birds of conservation concern: populations, trends and national responsibilities. - Cambridge, UK: BirdLife International

Burgas, D., Byholm, P. \& Parkkima, T. 2014. Raptors as surrogates of biodiversity along a landscape gradient. Journal of Applied Ecology 51: 786-794. DOI: 10.1111/1365-2664.12229

Chobanov, D. \& Milchev, B. 2020. Orthopterans (Insecta: Orthoptera) of conservation value in the Eurasian Eagle Owl Bubo bubo food in Bulgaria. - Travaux du Muséum National d'Histoire Naturelle "Grigore Antipa” 63(2): 161-167. DOI: 10.3897/travaux.63.e53867

Demerdzhiev, D., Dobrev, D., Arkumarev, V., Terziev, N. \& Georgiev, G. 2019. Distribution, abundance and breeding performance of Lesser Spotted Eagle Clanga pomarina Brehm, 1831 (Aves: Accipitridae) in Southeast Bulgaria. - Acta Zoologica Bulgarica Suppl. 14: 15-33.

di Minin, E. \& Moilanen, A. 2014. Improving the surrogacy effectiveness of charismatic megafauna with well-surveyed taxonomic groups and habitat types. - Journal of Applied Ecology 51(2): 281-288. DOI: 10.1111/13652664.12203.

European Commission 2021. NATURA 2000. https://ec.europa.eu/environment/basics/ natural-capital/natura2000/ index_en.htm

Gantioler, S., Rayment, M., ten Brink, P., McConville, A., Kettunen, M. \& Bassi, S. 2014. The costs and socio-economic benefits associated with the NATURA 2000 network. - International Journal of Sustainable Society 6: 135-157. DOI: 10.1504/IJSSOC.2014.057894

Geldmann, J., Manica, A., Burgess, N., Coad, L. \& Balmford, A. 2019. A global-level assessment of the effectiveness of protected areas at resisting anthropogenic pressures. - Proceedings of the National Academy of Sciences 116(46): 23209-23215. DOI: 10.1073/pnas.1908221116

Golemanski, V. (ed.) 2015. Red Data Book of Bulgaria. $2^{\text {nd }}$ ed. - Bulgarian Academy of Sciences and Ministry of Environment and Waters of Bulgaria, Sofia, Bulgaria

Kubacka, M. \& Smaga, Ł. 2019. Effectiveness of NATURA 2000 areas for environmental protection in 21 European countries. - Regional Environmental Change 19: 2079-2088. DOI: 10.1007/s10113-019-01543-2

León-Ortega, M., Martínez, J., Pérez, E., A., Lacalle, J. \& Calvo, J. 2017. The contribution of non-protected areas to the conservation of Eurasian Eagle-owls in Mediterranean ecosystems. - Ecosphere 8(9): e01952.10.1002/ ecs 2.1952

Margules, C. \& Pressey, R. 2000. Systematic conservation planning. - Nature 405: 243-253. DOI: 10.1038/35012251

Milchev, B. 2016. Dietary comparison of coexisting Barn Owl (Tyto alba) and Eagle Owl (Bubo bubo) during consecutive breeding seasons. - Animal Biology 66: 219-228. DOI: 10.1163/15707563-00002499

Milchev, B. \& Georgiev, V. 2012. Roach's Mouse-tailed Dormouse Myomimus roachi distribution and conservation in Bulgaria. - Hystrix 23: 67-71. DOI: 10.4404/hystrix-23.2-4779.

Milchev, B. \& Georgiev, V. 2014. Extinction of the globally endangered Egyptian Vulture Neophron percnopterus breeding in SE Bulgaria. - North-Western Journal of Zoology 10: 266-272. art.141601 http://biozoojournals.ro/nwjz/index.html

Milchev, B. \& Georgiev, V. 2020. Temporal and spatial dietary shifts of a generalist top predator: long-term study of an Eagle Owl Bubo bubo population. - Forestry Ideas 26: 366-379.

Milchev, B., Georgiev, V. \& Kovachev, A. 2019. Breeding failures of the Eagle Owl Bubo bubo: pros and cons of nesting in natural and human-made structures in SE Bulgaria. - North-Western Journal of Zoology 15: 75-83. art.181602 http://biozoojournals.ro/nwjz/index.html

Milchev, B. \& Menzel, J. 2017. Eagle Owl Bubo bubo diet indicates new localities of poorly known and threatened breeding birds in Bulgaria. - Vogelwelt 137: 289-294.

Milchev, B. \& Spassov, N. 2017. First evidence for carrion-feeding of Eurasian Eagle-owl (Bubo bubo) in Bulgaria. - Ornis Hungarica 25(1): 58-69. DOI: 10.1515/orhu-2017-0005

Ministry of Environment and Water 2021. NATURA 2000. https:/www.moew. government.bg/bg/priroda/natura-2000

Nedyalkov, N., Popgeorgiev, G. \& Staneva, A. 2018. Updated distribution of the elusive Roach's Mouse-tailed Dormouse, Myomimus roachi Bate, 1937 (Mammalia: Rodentia: Gliridae) in Bulgaria. - Historia Naturalis Bulgarica 29: 3-8.

Newton, I. 1979. Population Ecology of Raptors. - Poyser, Berkhamsted 
Nikolov, S., Kornilev, Y., Popgeorgiev, G., Stoychev, S. \& Georgiev, B. 2014. Challenges for habitat and species conservation in the NATURA 2000 network, Bulgaria: an overview from two Special Protection Areas. - Acta Zoologica Bulgarica Suppl.(5): 3-8.

Penteriani, V. \& Delgado, M. 2019. The Eagle Owl. - T \& AD Poyser, London, Oxford, New York, New Delhi, Sydney

Regos, A., Tapia, L., Gil-Carrera, A. \& Domínguez, J. 2017. Monitoring protected areas from space: A multitemporal assessment using raptors as biodiversity surrogates. - PLoS ONE 12 (7): e0181769. DOI: 10.1371/ journal.pone. 0181769

Rohrer, Z., Rebollo, S., Monteagudo, N. \& Talabante, C. 2020. Eagle Owl presence and diet at mining sites: implications for restoration and management for cliff-nesting birds. - Restoration Ecology 28(6): 1541-1550. DOI: $10.1111 /$ rec. 13256

Scherzinger, W. \& Mebs, T. 2020. Die Eulen Europas [Owls of Europe]. - Franckh-Kosmos Verlags, Stuttgart, D. (in German)

Scott, J. \& Schipper, J. 2006. Gap analysis: a spatial tool for conservation planning. -In: Groom, M. J., Meffe, G. K. \& Carroll, C. R. (eds.) Principles of Conservation Biology ( $3^{\text {rd }}$ ed.) - Sunderland, MA: Sinauer, pp. 518-519.

Sergio, F., Newton, I., Marchesi, L. \& Pedrini, P. 2006. Ecologically justified charisma: Preservation of top predators delivers biodiversity conservation. - Journas of Applied Ecology 43: 1049-1055. DOI: 10.1111/j.13652664.2006.01218.x

Sergio, F., Caro, T., Brown, D., Clucas, B., Hunter, J., Ketchum, J., McHugh, K. \& Hiraldo, F. 2008. Top predators as conservation tools: ecological rationale, assumptions, and efficacy. - Annual Review of Ecology, Evolution, and Systematics 39: 1-19. DOI: 10.1146/annurev.ecolsys.39.110707.173545

Trochet, A. \& Schmeller, D. 2013. Effectiveness of the NATURA 2000 network to cover threatened species. - Nature Conservation 4: 35-53. DOI: 10.3897/natureconservation.4.3626

Watson, J., Dudley, N., Segan, D. \& Hockings, M. 2014. The performance and potential of protected areas. Nature 515: 67-73. DOI: 10.1038/nature13947

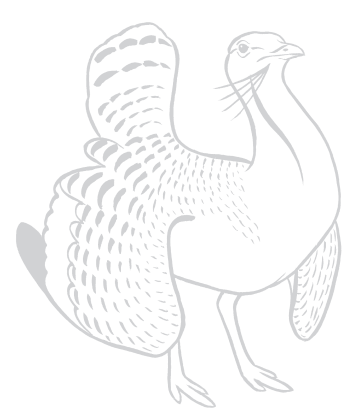

